ISPEC Tarım Bilimleri Dergisi

$2020: 4(3)$

(C) Telif hakk ISPEC'e aittir

Derleme Makalesi

\section{*Lale TAŞ}

Orcid No: 0000-0001-7113-0353

*GAP Tarımsal Araştırma Enstitüsü Müdürlüğü

laletas92@gmail.com

DOI

https://doi.org/10.46291/ISPECJASv ol4iss3pp704-716

Geliş Tarihi: 13/08/2020

Kabul Tarihi: 15/09/2020
E-ISSN:2717-7238

将P互C

www.ispecjournal.com
ISPEC Journal of Agr. Sciences

$2020: 4(3)$

Copyright C ISPEC

$\underline{\text { Review Article }}$

\title{
Organic Olive Growth Opportunities In The GAP Region
}

\section{Abstract}

Organic agriculture is a form of production that is controlled by all stages from production to consumption by using only the drugs allowed by the regulation and certified by control certification companies. Since the use of chemical pesticides in agricultural production, which increases day by day, remains in food as residue, it is dangerous for human health. Particularly because of the Pandemic affecting the world and various health problems, people become conscious of nutrition and prefer a production method that is friendly to human health. Organic Agriculture is an environmentally friendly way of production that gives priority to human health. Despite the favorable climatic conditions and fertile lands in the GAP region, we cannot say that organic agriculture has progressed sufficiently. In this study, the organic cultivation possibility and potential of olive and olive oil production, which is a consequential product for the Southeastern Anatolia Region, will be examined. In the study conducted as a compilation, the experience and observations of the researcher in the region and secondary sources, official reports and statistics were used.

\section{Keywords}

Olives, organic olives, organic olives oil, organic farming, organic production, GAP 


\section{INTRODUCTION}

Some of the most primary problems of human beings; We can say that unconscious use of natural resources, developing industry, increasing population. It harms the environment, as we misuse natural resources, reuse of natural resources decreases (Aksoy et al. 2000; Sevin et al. 2018). In order to increase agricultural production, activities in agricultural production accelerated in order to produce enough food for people for the growing population under the name of green revolution in agriculture between 1960 and 1970. It was necessary to increase production in order to provide enough food for this growing population. Therefore, producers are directed to use chemical pesticides, pesticides, hormones, mineral fertilizers in agricultural production. With the use of these inputs, residues such as pesticides and pesticides in foods, causing environmental pollution and disrupting the natural balance have encouraged producers to engage in ecological agriculture. It also encouraged consumers to consume natural products (Kaftanoğlu, 2003; Keyvan et al., 2018; Tutkun et al., 2019). Organic products export ratio is high in Turkey. Organic products export ratio is high in Turkey. Besides, the domestic market in organic agriculture production is developing day by day. However, although our country has a suitable climate and soil structure for organic agriculture production, its footprint in food marketing worldwide is miniature. That is why, it is critical for the growth of organic production exports by extending organic agriculture in our country (Demiryürek, 2011). In 1984, organic farming activities of foreign companies in Turkey began with demands for organic raisins and dried figs (Özdemir, 2016). The Regulation on the Principles and Implementation of Organic Agriculture dated 18.082010 and numbered 27676 was published in the Official Gazette. This regulation was prepared bases on the Organic Agriculture Law numbered 5262 and dated 01.12.2004 and entered into force as of 01.01.2009 and is compatible with the EU's regulation no 834/2007. The amendment of the regulation on the principles and application of organic agriculture dated 06.10.2011 and numbered 28076 was published in the Official Gazette (Karaaslan, 2012). The purpose of the regulation; to design organic farming activities, to plan organic farming production, to regulate the marketing of organic farming products, to improve organic farming and to spread organic 
farming (Karaaslan, 2012). In the same regulation 14.08.2012 (Official Gazette No.28384), 24.05.2013 (Official Gazette No.28656), 15.02.2014 (Official Gazette No.28914), 22.07.2013 Necessary arrangements were made according to the conditions of the day in 2015 (Official Gazette No. 29422) and 10.01.2018 (Official Gazette No. 30297) (Boz ve Kaynakçı, 2018). GAP (Southeastern Anatolia Project) area is one of the first regions in the world where agriculture is cultivated. GAP region has suitable climatic conditions and fertile soils. Since the region also has abundant water resources, it consists of basins where a wide variety of products can be grown according to all seasons. The lands in the region are not fragmented yet. This is a positive factor for organic farming. The fact that the lands are not fragmented reduces the rate of chemical-synthetic drug contamination from other lands. With organic agriculture production, it will be possible to increase soil fertility and sustainable use of natural resources in the GAP region. Various scientific studies on organic agriculture have been carried out in the Southeastern Anatolia Region until today. Çelik (2019) stated that the cluster model is the most effective method to increase organic agricultural production and that the GAP Organic Agriculture Cluster, which is active in the GAP region, contributes to the development of the GAP region. In the study conducted by Taş et al. (2016) in Şirvan district of Siirt Province, the organic cultivation of Zivzik pomegranate, which is grown in the district, was examined. It has been determined that the farmers in the research area are willing to grow Zivzik pomegranate organically and they determined that the transition of Zivzik pomegranates to organic Zivzik pomegranate could be fast with the establishment of the organic pomegranate juice processing factory in the research area. Çetinkaya et al. (2013) stated that the GAP region is very abundant in terms of some plants. For example, some of them are medicinal and aromatic plants, oilseed plants. Some of the leading products of the GAP region Karacadağ paddy, red lentil, Mardin cherry, Siirt Zivzik Pomegranate, Şire grape, durum wheat, Diyarbakır watermelon, Lice tomato. Bengisu et al. (2010) GAP is a region with fertile soils for organic agriculture. However, she stated that organic agriculture and organic animal husbandry should not be considered separately from each other. Organic livestock farming is consequential for input 
into organic production. Özdemir et al. (2009) determined that the region has an important potential in terms of organic viticulture. Clumsy et al. (2011) for the production of olives and olive oil development in Turkey plays an important role. It spreads over a wide area in Turkey and there is a lot of olive varieties. It is mostly grown in the coastal areas, in the Aegean and Mediterranean regions. With the support applied in our country, the olive production area and the number of olive trees are increasing. The purpose of this study is to reveal the organic olive produce potential of the GAP region and and to investigate the current status and future impact of organic olives as organic herbal production. In this research, it is primarily aimed to determine the characteristics of the region that are suitable for organic agriculture. Then, the current situation of organic olive oil and organic olive production and the studies on this subject will be stated. Finally, it is aimed to determine the solutions to be implemented and strategies to be developed to increase the production of organic olive and olive oil.

\section{MATERIALS and METHODS}

As the research is a compilation, secondary data sources were used. The relationship and communication with the people and institutions related to the olive and olive oil sector in the field of research have been effective in the increase of the researcher's knowledge and experience on the subject. In this context, institutions and organizations that benefit from both printed materials and official records are Gaziantep İpekyolu Development Agency, Karacadağ Development Agency, Dicle Development Agency, GAP Regional Development Administration, Ministry of Agriculture and Forestry, Provincial Directorates of Agriculture and Forestry, Harran University and Turkish Statistical Institute. In the introduction to the research, the development of organic agriculture legislation in Turkey, Suitability of the GAP Region for organic agriculture, previous studies on the subject and The aims of the research have been determined. The material used in the review study in the material and method part and The method followed is explained. Organic agriculture in the GAP Region in the section of the research findings and The current situation and future potential in organic olive and olive oil production are examined. It was concluded by specifying the measures to be taken for the widespread organic olive and olive oil in the study area. 


\section{Research Findings Organic Agriculture In The GAP Region}

Various studies have been carried out by national and international organizations to spread organic agriculture in the GAP Region until today. One of these organizations is the GAP Regional Development Administration and carried out many activities between 2009 and 2019 to spread organic agriculture in the region. GAP region in Turkey for the first time in three development agencies (Karacadağ Development Agency, Dicle Development Agency, İpekyolu Development Agency) and the GAP Regional Development Administration in collaboration was prepared GAP Organic Agriculture Value Chain Financial Assistance Program in 2015. 32 pilot projects have been implemented within these plans. A total of 12,335,918.39 TL was spent for the projects (Tektak et al., 2018, Anonymous, 2019). Within the activities of these projects, a total of 74 activities were implemented in November 2012-July 2019, including visits to 21 fairs, including 15 domestic and 6 international visits, 47 training activities, 6 technical trips and 3 of them domestic and 3 abroad. 836 people in fair events, 2008 people in training activities, 100 people in technical trips, these activities were implemented with the participation of a total of 2,944 people (Tektak et al., 2018, Anonymous, 2019a). GAP Organic Agriculture Cluster Association GAP ORKÜDER started its activities on 03.06.2016 for the sustainability of all activities implemented to promote organic agriculture to raise awareness in civil society on organic agriculture in the region and to support studies. Various brands have been got, for example, Kilizi, EKOREZ, Web Portal has been activated, brands such as GO, Eğil Organic have been brought to the market. Necessary support has been provided for the registration of these brands. The project earned the ESCA Bronze Cluster Excellence. On 16-17 November 2017, the Şanlıurfa declaration was signed with the stakeholders of the GAP Organic Agriculture Cluster Project and the relevant institutions with a total of 143 participants with the "Organic Agriculture Forum for Sustainable Development". scalable and prepared for the first time in Turkey repeatable tool set, making printing has been communicated to the relevant stakeholders (Diamond et al., 2018). scalable and prepared for the first time in Turkey repeatable tool set, making printing has been communicated to the relevant stakeholders (Diamond et al., 
2018). The biggest difference from other parts of Turkey GAP region in organic crop production GAP Organic Agriculture Cluster Project site in 2015 and in 2016 established for financial support programs made with development agencies GAP Organic Agriculture Advisory and Extension Center (GAP OTADAM). With GAP OTADAM, the private sector in the organic agriculture value chain in the GAP region and GAP Organic Agriculture Cluster members were provided with information on marketing of organic products, production and processing of organic products. It is also aimed to contribute to the dissemination of organic agriculture production in the region (Anonymous, 2019b). The United Nations Food and Agriculture Organization (FAO) and the Agriculture and Forestry Ministry implemented in 2010. Strengthening Organic Agriculture in Turkey (UTF / TUR / 052) in the Southeastern Anatolia Project of the studies were conducted and the region where the very high potential for organic farming it has been concluded (Boz et al., 2011). The main purpose of the project is to provide basic and adequate nutrition, to develop a very high agricultural sector that attaches importance to social and environmental concerns and sees food safety as the most important issue. For this purpose it was emphasized to Ensuring the use of quality seeds and saplings, educating farmers, strengthening producer organizations, supporting research and development activities, increasing the competitiveness of agricultural enterprises and increasing productivity by improving the marketing framework. The opportunities of the Southeastern Anatolia Region in terms of organic agriculture in the project are listed as follows: Due to Turkey's most important agricultural projects of the GAP project of continuous investment, increasing irrigation opportunities day by day, the presence of large and untouched agricultural lands in the region, the climate and soil conditions are suitable for organically growing many plants and various alternation plans can be put into effect, The fact that agricultural pesticides are not used at an excessive level and therefore the transition period to organic agriculture is shorter and many endemic species grow naturally in the region. Besides the fact that the region is suitable for eco-tourism and religious tourism is the opportunities that support organic production (Boz et al., 2011). Ministry of Agriculture and Forestry, the Organic Farming Information System 
(OTBİS) between the years 2015 to 2019 according to Organic Vegetable Production Data in Turkey (Figure 1) is given. To develop organic agriculture in the Southeastern Anatolia Region, both the legislative work carried out by the state, and corporate and non-governmental initiatives have positively affected the increase of organic agriculture production. Organic production areas in the region between 2015-2018, the number of farmers who adopt organic agriculture and the number of organic products has increased. However, in 2019, the number of farmers organic agriculture and the number of organic production showed a slight decrease (figure1).

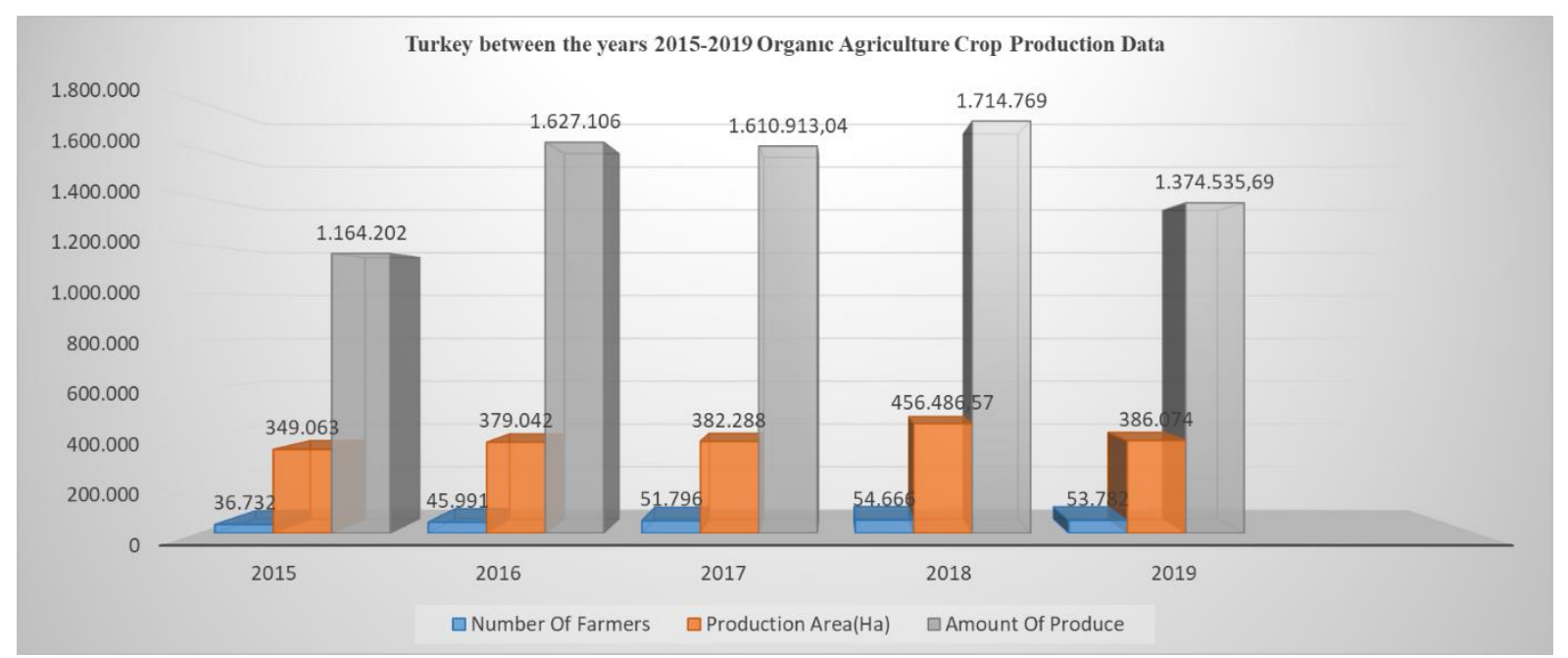

Figure 1. Turkey between the years 2015-2019 Organic Agriculture Crop Production Data

\section{Organic Olive Growing And Organic}

\section{Olive Oil Production In The Gap Region}

The homeland of olives is Upper Mesopotamia, South Asia and Southeast Anatolia. Olive was cultivated in the eastern shores of the Mediterranean in $3000 \mathrm{BC}$. Olive is one of the first fruits cultivated in the Mediterranean. Olive has a very important place in the consumption and economy of people in Mediterranean countries (Çiftçi et al.2019). The clearest hint about olive oil was encountered in 4500 $\mathrm{BC}$ and in the Cretan Civilization in the Mediterranean (Tunal1, 2008). These clues prove that olive cultivation was taken into the culture in the Mesopotamian lands in 4000 BC (Tunalığlu, 2010). Worldwide most countries bordering the Mediterranean (Spain, Italy, Greece, Turkey, Tunisia, Syria, Morocco, France and Portugal) olive cultivation is carried out (Clumsy, 2015, Anonymous, 2019c). The GAP region has 
major potential for organic agriculture, which produces raw materials for different business lines Covering a large agricultural land (Bengisu, 2014). According to the data of Organic Agriculture Information System (OTBIS) 2019 of the Ministry of Agriculture and Forestry; There are 14.411 producers engaged in organic olive production in Turkey. The organic production area is $60.874,57$ ha. $154.736,25$ tons of organic products were obtained annually. When the table below is examined, while the organic olive production area and production amount increased between 2015 and 2017, it is observed that the production area and the production amount decreased after 2017.

The reason for this decline in organic olive production after 2017 may be the decrease in the grants and activities of some public institutions and development agencies (figure2).

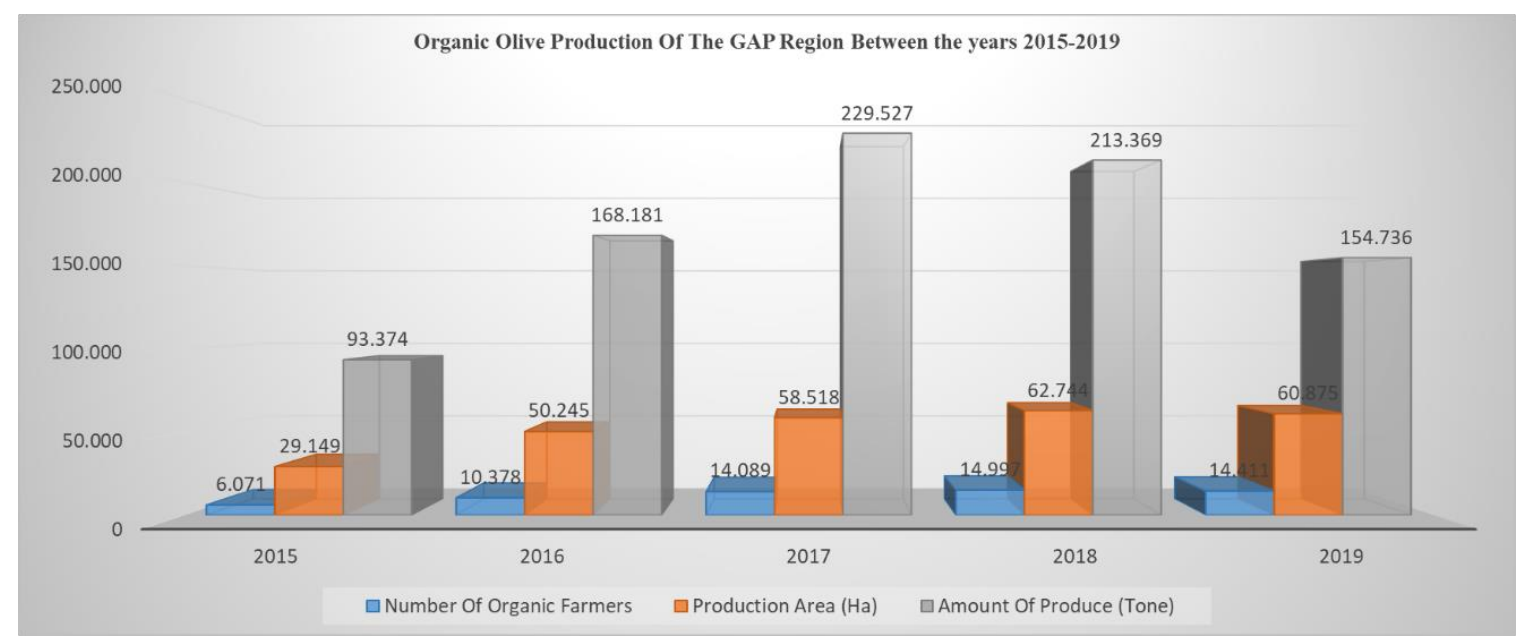

Figure 2. Organic Olive Production Data of the GAP Region between 2015-2019

According to the data of Organic Agriculture Information System (OTBİS) 2019 of the Ministry of Agriculture and Forestry; Turkey has 8.876 manufacturers engaged in olive production in transition. Production area in the transition period; It is $21.556,10$ ha. 51.650,06 tons of ecological products were obtained annually. Organic Olive and Olive Oil facilities in the region; Domestic and international sales are made with the brand "Kilizi" in Kilis and "Ebrulim" in Şanliurfa and "Deriko" in Mardin. Producers producing organic olives in Kilis established the "Kilis Province Central District Organic Olive Producers Union" on 06.05.2011. Union, within the scope of the project; He established the Kilizi Integrated Organic Olive Oil Facility and worked on branding for a long time. After long studies, the "Kilizi" brand, which 
also resembles the name and characteristics of the province, has been registered (Anonymous, 2020d). Kilis Province Central District Organic Olive Producers Union has 350 members. Kilis Province Central District Organic Olive Producers Association launched organic olives as organic olive oil in 2019. In the "Mesopotamia Olive Oil Facility" opened in 2018 with the project "Olive is raising in its homeland" by Derik Development Association; It is put on the market as olive oil and table olives. Harran University Department of Horticulture Department academic staff member Assoc. Dr. "We produce organic olive oil for healthy tomorrows" project by Ebru SAKAR with the support of Karacadag development agency, GAP Regional Development Administration, UNDP, HÜBAK and Harran University, "Ebrulim Olive Oil Facility" was established. The facility has a daily olive processing capacity of 40 tons. The products at the facility are offered to the market as table olives and olive oil under the brand name "ebrulim".

A-Some Studies on Organic Olive Production and Olive Oil Made by Universities in the GAP Region;

"A research on determination of the current situation and development opportunities in
Olive Growing and Processing Industry in the GAP Region", 15/12/2008 - 30/12/2015 "Establishing an organic olive processing facility within the Harran University Faculty of Agriculture", Scientific research project supported by Higher Education Institutions, 23/07/2014 - 22/07/2016 "Şanlıurfa Produces Organic Olives in Hope, Looking to the Future", supported by the Ministry of Development 10/11/201512/12/2016 "We Produce Organic Olive Oil for Healthy Tomorrows", Supported by public institutions (except Higher Education Institutions), 20/12/201608/12/2017 "The project of pickling at health tables with organic olives".by Harran University, Ministry of Development, Project Coordinator, 16/12/2016 "Healthy flavor 2 project with organic olives" by Harran University, TRC1 16 GAPODZ 2 0002, Ministry of Development, Project Coordinator, 22/08/2016 Kilis 7 Aralık University implemented the "Development and Expansion of Olive Varieties Suitable for Organic Agriculture with Biotechnological Methods" project in Kilis.

B-Some Studies of Non-Governmental Organizations on Organic Olive Production and Olive Oil in the GAP Region; 
"Healthy Flavor Project With Organic Olives"and "Healthy Flavor With Organic Olives 2 Project" was been executed By Kilis Province Central District Organic Olive Producers Union in Kilis "Olive Oil Bottling Packaging Storage project" By Kilis Province Organic Olive Producers Association-2012 Kilis Province Organic Olive Producers Association "Pilot Project for Increasing the Competitiveness of Organic Olive Oil in Kilis Province " has been implemented in Kilis. Derik Development Association has implemented the " Olive Ramps in its Homeland " project in Derik. Nizip Chamber of Commerce has implemented the most "Naturally Nizip Organic Olive Project" in Nizip. Thanks to these and similar projects supported in the GAP region, the awareness of organic agriculture producers has increased and a new vision has been developed and these visions have affected every stage of production over time. One of these effects has been the increase in income level, for example, by selling its products to domestic and foreign markets under the name of its brands. It has had a positive impact on the socio-cultural sphere and has also affected the lifestyle of the family members over time. In the GAP region, there has been a significant increase in organic agriculture and organic olive production in the area, especially between 2009-2017, with the work of stakeholders and producers trained within the scope of the "GAP Organic Agriculture Cluster Project" activities. Due to the Pandemic, which has taken the world under its influence, the whole world requires healthy eating It realizes once again how important it is for a healthy life. In order to ensure the sustainability of organic agriculture in the region, taking the necessary steps to make it more active by increasing the "GAP Organic Agriculture Cluster Project", similar support packages such as the grant support of Development Agencies and the activities of the Ministry of Agriculture and Forestry to disseminate organic agriculture will provide positive contributions. Thanks to the production of organic olives and olive oil produced in the GAP region, the people of the region can consume these products at a more affordable cost. In this way, consumers find the opportunity to eat healthier.

\section{DISCUSSION and CONCLUSION}

According to the climatic conditions of our country, despite being a very isolated area with fertile soils and organic agricultural production in Turkey and in this context it is not enough organic olive production levels. According to the 
potential of our country, organic olive production can be increased in the relevant basins with projects that include various support packages and dissemination activities for existing organic olive production. It is a periodicity of the problems for the producer in organic olive production. In other words, the fruit yield is a year less than a year. Therefore, suitable olive varieties should be selected to reduce the loss in this situation. As a result of the Projects supported and implemented in the GAP region, Kilis Province Organic Olive Producers Union in Kilis in the GAP region; "Kilizi Integrated Organic Olive Oil Facility", "Mesopotamia Olive Oil Facility" under Derik Development Association in Mardin "Ebrulim Olive Oil Facility" established within Harran University in Şanliurfa is produced and marketed in Turkey and abroad. Buying a brand for the products of the said facilities is important in terms of national and international competitiveness and sustainability of the product. These 3 olive oil producers had the opportunity to promote their products by participating in domestic and international fairs, thanks to other projects supported by the GAP Regional Development Administration in the region, especially within the scope of the "GAP Organic
Agriculture Cluster Project". Also, projects should be developed to improve the promotion and marketing network. Participation in the organic agriculture sector can be encouraged by developing package programs to support the private sector. In cooperation with all public institutions and organizations, organic agriculture can be sustained in the GAP region.

\section{REFERENCES}

Aksoy, U. 2000. Kaynak koruyucu girdi kullanımı. V. Türkiye Ziraat Mühendisliği Teknik Kongresi.

Anonim 2018 http://www.gap.gov.tr/ (Erişim Tarihi: 16.07.2019)

Anonim 2019a http://www.gap.gov.tr/ (Erişim Tarihi: 16.07.2019)

Anonim 2020b http://www.gaporganik. org/ (Erişim tarihi: 18.07.2019)

Anonim 2019c http://www.fao. org /faostat/ (Erişim tarihi: 18.07.2019)

Anonim 2019d https://www.kilizi.org/ (Erişim tarihi: 18.07.2019)

Bengisu, G. 2014. GAP Bölgesinin Organik Tarım Potansiyeli ve Uygulanabilirliği. Alınteri Tarım Bilimleri Dergisi. 26(1):38-44.

Bengisu, G., Yavuzer, Ü., Cevheri, C., Öztürkmen, A. R., Coşkun, M. 2010. Organik Tarımın Gap Bölgesi'nde 
Uygulanabilirliği. Türkiye Ziraat

Mühendisliği VII. Teknik Kongresi. 11-15

Ocak, Ankara.

Boz, İ., Aksoy, U., Özçatalbaş, O. 2011.

Türkiye'de Organik Tarımın

Güçlendirilmesi (UTF/TUR/052) Çalıştay ve Eğitimler. Birleşmiş Milletler Gıda ve Tarım Örgütü (FAO) ve Gıda Tarım ve Hayvancılık Bakanlığı.

Boz, İ., Kaynakçı, C. 2018. Possibilities of Improving organic farming in Turkey. International Journal of Innovation and Economic Development. 5(4):25-34.

Çelik, F. 2019. Gap Organik Tarım Kümesi'nin Bölgesel Kalkınmaya Etkisinin Değerlendirilmesi. Aksaray Üniversitesi Sosyal Bilimler Enstitüsü Dergisi, 3(2), 220-242.

Çetinkaya, H., Kendal, E., Sayar, M. S. 2013. Ekolojik Tarım Açısından Güneydoğu Anadolu Bölgesi. Turkish Journal of Scientific Reviews, 6(1), 195198.

Çiftçi, Z., ve ark. 2020. Dünyada ve Türkiye'de Zeytinde Yapılan Doku Kültürü Çalışmaları. Türk Tarım - Gıda Bilim ve Teknoloji Dergisi, 8(3): 645-650.

Demiryürek, K., 2016. Organik Tarım Ve Ekonomisi, Giresun, 1 s.

Demiryürek, K., 2004. Dünya ve Türkiye'de Organik Tarım. Harran
Üniversitesi. Ziraat Fakültesi Dergisi, 8 (34):63-71.

Demiryürek, K., 2011. Organik Tarım Kavramı ve Organik Tarımın Dünya ve Türkiye'deki Durumu, GOÜ, Ziraat Fakültesi Dergisi, 28(1): 27-36

Sakar, E., 2011. Türkiye'de zeytin yetiştiriciliğinin durumu ve ülkemizde yapılan bazı seleksiyon ve adaptasyon çalışmaları. HR.Ü.Z.F. Dergisi, 15(2): 1925

Gap Bölge Kalkınma İdaresi Başkanlığı ve http://www.gap.gov.tr/

Kaftanoğlu, O. 2003. Ekolojik ve organik arı ürünleri üretimi. 2. Marmara Arıcılık Kongresi Bildiri Kitabı, Yalova, 209.

Karaaslan, V., 2012. Organik Tarım 2 . (Güncellenmiş ) Baskı 2012,Ankara. 39 s.

Keyvan, E., Yurdakul, O., Kocasarı, F., Tutun, H., Demirtaş, A., Kahraman, H. A., Erdi, Ş. E. N. 2018. Detection of ochratoxin A in bulk tank milk. Kocatepe Veteriner Dergisi, 11(3), 255-259.

Özdemir, G. 2016 Diyarbakır İlinin Organik Üzüm Yetiştirme Potansiyeli ve Yaygınlaştırılması Faaliyetleri. GAP TEYAP Tarımsal Eğitim ve Yayım Projesi Dergisi, 3:22-23.

Özdemir, G., Karataş, H., Bayram, A., Doran, İ., Gül, İ. 2009. GAP Bölgesi 
Organik Bağcılık Potansiyeli ve Organik Tarım Uygulamaları, 1. GAP Organik Tarım Kongresi, 144-155.

Sevin, S., Kuzukiran, O., YurdakokDikmen, B., Tutun, H., Aydin, F. G., Filazi, A. 2018. Selected persistent organic pollutants levels in the Ankara River by months. Environmental monitoring and assessment, 190(12): 705.

Taş, L., Boz, İ., Akbay, C. 2016. Siirt İli Şirvan İlçesinde Organik Zivzik Narının Benimsenmesi ve Yayılması. XII. Tarım Ekonomisi Kongresi Bildiriler Kitabı. 2527 May1s, Isparta. s.1127-1136

Tutun, H., Kahraman, H. A., Aluc, Y., Avci, T., Ekici, H. 2019. Investigation of some metals in honey samples from West Mediterranean region of Turkey. In Veterinary Research Forum (Vol. 10, No. 3, p. 181). Faculty of Veterinary Medicine, Urmia University, Urmia, Iran.
Tunalı, A. .2008. Ege Yakası. Aylık, Aktüel, Kültür ve Sanat Dergisi. Sayı:2. Y11 $1 \mathrm{~S}: 18-19$. Aydin

Tunalığlu, R. 2010. Ülkemiz Zeytinciliğindeki Gelişmeler. ZeytindostuMardin Valiliği. 7. Ortak Akı1 Toplantısı. 9 Nisan 2010. Panel Konuşması. Mardin

Tektaş A., Özertan G., Helvacioğlu A.D. ve Karapınar B. 2018. GAP Organik Tarım Küme Projesi Ölçeklendirilebilirlik ve Tekrarlanabilirlik Araç Seti; GAP BKİ, Şanlıurfa, Türkiye.

Sakar, Z. Zeytinyağı sektörünün gaziantep ilinde mevcut durumu ve ekonomik analizi, Harran Üniversitesi Fen Bilimleri Enstitüsü Yayınlanmamış Doktora Tezi, Şanlıurfa, 2015, s. 1. 